\title{
COMMERCIALIZATION OF HIGHER EDUCATION THROUGH MEDIA SERVICES IN PAKISTAN: A CRITICAL REVIEW
}

\footnotetext{
Habib Elahi ${ }^{1}$, Sadaf Naz $^{2}$, Azhar Rashid ${ }^{3}$

${ }^{1}$ Assistant Professor, Department of Education, Hazara University Mansehra

${ }^{2}$ Assistant Professor, Department of Education, Hazara University Mansehra

${ }^{3}$ Lecturer, Department of C.M.S, Hazara University, Mansehra
}

\section{A B S T R A C T}

Education system in Pakistan does not cater for the need of the society especially inculcating the unity of thought, skills and attitudes among the learners. The serious efforts to improve the standard of Higher Education for the commercialization of education especially higher education have not been made by the government. A number of policies were framed for the betterment of the education system but there could not be a single unanimous policy framed and materialized. Pakistan is a country that has invested meager resources in education sector. The countries which invested in human resource are now leading the economic arena and are counted as developed countries. With reasonable allocation of funds and expertise in this field, the priorities can be fixed to correlate with the standards of the higher education of developed countries. Higher Education Commission or the like bodies of developed countries have played a pivotal role in making their educational standards and these are role model for Pakistan. In this respect some practicable suggestions are recommended for enhancing the marketability and commercialization of education in Pakistan.

KEYWORDS: Capital structure, HEC, Pakistan, Quality Education, Govt. Policies, Budget allocation, Training and Research.

\section{INTRODUCTION}

The 21st century is considered to be the century of information and it is changing and marching ahead in this contemporary society at an unprecedented speed. The modern world seems like a global village that leads to foster a sense of community development among its inhabitants which is based on global educational harmony and mutual 
cooperation. In this age of information exchange, exposing of knowledge and emergence of new technology, choosing a university and planning one's career involves important and difficult decision on the part of a student as well as parents. Such scientific and technological strides of humanity have altogether changed the international scenario. Students as an integral segment of any society also look to their academic pursuits to be acknowledged in international perspective; hence strive for the type of degree that is more of global nature than specific. In such a scenario, universities are supposed to play the role of a counseling body for the better career choices of the students.

\section{Higher Education in Global Perspective:}

As compared to other countries of the world, Pakistan has limited sources and facilities of quality education. There are few World ranking educational institutions in Pakistan. On the other hand, in developed countries, socio-economic development is directly related to the latest scientific and technological knowledge. This important aspect has been realized by nearly all states; hence, they tend to invest more in human resource development.

A single company in Finland (the total population of which is equal to the $1 / 4$ th of Karachi city) exports almost a double of the total exports of Pakistan. Malaysia, a relatively small country in the Far East, allocated $30 \%$ of its GDP to be spent on education as a result of which this country is considered as the Asian Tiger in the economic arena. Definitely the other sectors suffered a lot but they set the priority by placing education at top of their agenda. The policies have brought the fruit in shape of the rapid and unprecedented growth in their economy, and now Malaysia is exporting over $86 \%$ of the total high tech to the Muslim world while is placed ahead of many European countries.

South Korea is another example that prioritized education in the 1960s during this period just 5\% of Korean youth (17-23 years of age) had access to higher education quite similar to today's Pakistan. Only $\$ 30$ billion was the volume of Korean exports in the 1960s. However, this is pertinent to mention here that by the year 2010, this country had increased higher education enrollment to the world highest level (95\%). This gave boost to the country's economic growth by raising its exports volume to $\$ 360$ billion 
(Akbar, 2002).

China is spending $\$ 690$ billions on science and technology every year. China has reserved huge amount as scholarships for foreign students as well. In the modern world, socio-economic development of the countries depends upon the standard and quality of education in the country. In view of the above it can be concluded that education is the only key to open the doors of prosperity, progress and bright future of the nation.

\section{Education in Pakistan-Background:}

Fifty million people are illiterate in Pakistan and six lack school going children are out of school (UNESCO report 2007) (Akbar, 2003). According to 1987 census, literacy rate in Pakistan is $26.2 \%$ while Govt. of Pakistan (finance division) survey tells literacy rate $31.5 \%$ in Sindh, 27.4\% in Punjab, 16.3\% in KPK and 10.3\% in Baluchistan. FBS (2010) declare that Pakistan has 56\% literacy rate. There are certain reasons behind low literacy rate and low standard of education in Pakistan, namely carelessness of parents from their children, child labor, ignorance, people unawareness, lack of funds, lack of planning, corruption poverty. Moreover, in villages parents don't send their children, especially females, to schools that why literacy in females is very low. It is necessary to emphasis over female education so that they may actively participate in development and prosperity of the nation (Akbar, 2004).

However, the issue of literacy, standard of education, examination system, medium of instruction, teacher's training and curriculum is in critical condition. Moreover, due to lack of funds educational structure is not up to the international standard. There are limited lab facilities in schools, colleges and even universities. Planning commissions could not prepare the uniform policy for education in the country. There are a number of educational systems running at a time. There are government schools, private schools, English medium schools, Urdu medium schools, Islamic Madrassa schools, semi-private schools, and a chain of Army Public Schools. By nature and structure, all these are very much different from each other and their examination and intakes are totally contrary to one another. Every political party makes sweet promises for betterment and uniform policy of education but after coming in power their priorities change. A number of educational conferences were held in 1974, 1980, 1985, 1990 and 
1995, in which education policies were prepared and a target of $80 \%$ literacy rate was fixed but never gained yet. Former Prime Minister Shoukat Aziz said while talking to federal cabinet meeting that Govt. has decided to raise literacy rate form 53\% to 85\% within next five years (Ameen, 1992).

Pakistan has a very lower literacy rate. Today, the common man's life is full of frustration \& desperation, this may be in business sector, import-export, employments, financial planning, food production, health, shelter, law \& order, addiction and pollution, all these are the outcome of sub-standard educational system and low literacy rate.

Atta-e-Rehman (2011) believes that low public investment is the root cause of low literacy rate in Pakistan. So, a negligible ratio or percentage of the GNP is allocated to education that it could not address the issue of low literacy in Pakistan. The total allocation that was just $02 \%$ in the history has been raised to only $2.5 \%$, again a very shabby share. There is absence of fraternity with respect to the allocation of funds for the three-tier system in Pakistan as the primary education receives the lowest ratio of amount. This state of affairs has led to comparatively low literacy rate in Pakistan. Quality education, science and technology, entrepreneurship, together with just and effective governance ensures economic growth.

This of course, is very deplorable that being a nuclear state Pakistan stands at the bottom seven countries of the world that have low literacy rate. The reason can be many. One reason, and probably the most potential one, is the feudal system where the feudal lords occupy the parliament and do not want to impart education to the peasants and working class, hence, they are held in utter slavery. In sharp contrast to Pakistan, India abolished the feudal system as early as in the 1954 together with a uniform system of education for the citizens. However, in the recent decade (2002 onwards), with the rejuvenation of HEC, Pakistan achieved tremendous progress in higher education. Such strides led the country that her universities are included in world ranking. Of the top 600 World universities' ranking some of the Pakistani institutions stood at: NUST on 273 and UET Lahore at 281 and LUMS Lahore in the top 300. Unfortunately, this progress was curtailed in 2008 when the HEC budget and the related projects were reduced to almost $50 \%$ and $90 \%$ respectively. Regarding the fake degrees of the parliamentarians, 
the HEC had to authenticate or recognize the same in which 53 of the parliamentarians had forged degrees together with a total of 250 suspected degrees.

\section{Need for Pre-service Training for Teachers:}

In the past, teacher training aspect for university teachers was almost neglected. Even the university teachers were arrogant to join training courses pertaining to the study of educational theory and practice as they thought it against their prestige. Though the situation has now a little bit changed as refresher courses are arranged in universities which are directly supported by the HEC, yet teacher- training especially in -service has yet to attain a compulsory status in the universities. In this connection the recommendations of the National Committee on Teacher Education (1976) are worth mentioning: that Pre-service and in-service training programs be initiated for the professional growth and competence of college and university levels teachers; that to initiate a one-semester course prior to teaching at higher level together with a six weeks training program for in-service teachers at college and university level teachers.

This idea was somewhat addressed after the 1992 education policy an Academy of Higher Planning \& Management" was established under UGC (today's HEC). The National Education Policy (1992) recommended regular in-service training programme for teachers at all levels including the University.

The idea and practice of teacher training was also expounded in the National Educational Policy (1998). According to the policy, much of the strength of the graduate study programmes and the quality of research is determined by the quality of teachers. We need a wide range of faculty development porgrammes for university teachers to fill the gap of qualified manpower. To address this aspect of the teacher training, the Higher Education Commission (HEC) Pakistan initiated many such programs that were meant for the improvement of higher education. In this respect, the HEC has carried out a number of "Faculty development programs for the young universities teachers.

Instead of all this most of the universities recruit staff on the basis of degrees and performance in the interview. It should be compulsoryfor teachers to get pre-service training at higher education level.

Carrol (1995) asserts that the quality of Higher Education in any country is 
directly dependant on the quality of teachers together with the teaching-learning materials, content and methodologies as well as physical facilities. Besides these, a just, valid and reliable system of evaluation ensures quality in the educative process.

\section{Commercialization of Education in Pakistan:}

In the face of the rampant commercialization of our education sector, it is worth pondering whether Pakistani institutions are imparting any knowledge at all of merely dishing out "degrees." Formal education in schools, colleges and universities enables the learners to learn skills and gain specialized knowledge in particular fields, both of which collectively make one more employable. Generally speaking, the higher the educational qualification one has, and the more years of relevant experience on has acquired, the better are the salaries one is in a position to demand.

But the true purpose of education (as is implicit in the very origins of the word) is much broader than merely serving as a means towards one's professional aspirations. Education system should the potential to reach the roots of one's personality so that it may inculcate positive change, transform attitudes, dispositions and affect the fundamental commitments of individuals and society as a whole. In todays globalize world however like everything else, education too has been commoditized. Degrees are literally up for sale in most higher education institutions in Pakistan and around the world. Even at the lower primary and secondary levels, a variety of choices are available depending upon what you can afford. As noted in the October-December 2002 issue of the UNESCO's newsletter Education Today, “Like other public services, higher education too is slowly being drawn into the world of the market, students are now consumers, free to choose the best courses and there is big money to be made by private firms" (Atta-e-Rehman, 2011).

Education sector has brought some degree of improvement in the quality of education being given at some institutions (as various institutions compete to get the most students), but somewhere along the line, all this market competition has nevertheless gone on to be in close juxtaposition with the educational objectives of imparting knowledge to majority of the masses. The clash has been at two levels in Pakistan: one, the system that is cultivated has increasingly marginalized the majority of the country's 
poor, and even middle class, many of whom are not affluent enough to afford even the relatively nominal fee of state-funded higher educational institutions, let alone talk about the exorbitant tuitions fee of private educational institutions. This is a direct infringement of the right to attain education, which is envisaged in charter of the Universal Declaration of Human Rights.

But when one commercializes and commodities something that is essentially a person's fundamental right, and which in a welfare state at least, is the responsibility of the state to ensure provision of, one is opening yet another door for generating inequality and disharmony in society. The inferiority complex suffered by graduates of most publicsector universities in Pakistan, even those who have a long standing, and rich academic history, vis-à-vis their counterpart alumni of private institutions, no matter of what repute, is glaring exemplification of this phenomenon.

Secondly, and more importantly, on most occasions, it is questionable if Pakistani institutions are imparting any knowledge at all, or merely dishing out "degrees". In Pakistan, like in most other developing countries, the apparent profitability of this sector has drawn a vast member of entrepreneurs into the so-called "educational business". Such people clearly have no other honorable aims for entering this field apart from making a profit, and the result of this is directly manifested in the product of their pseudo-educational institutions.

Such ventures, thus, are now a ubiquitous sight in most urban cities with small private schools, colleges and even universities springing up every nook and corner of the country. In most cases though, such institutions have not received any formal recognition by relevant local educational governing bodies. Consequently, there is no guarantee of their degrees of diplomas being accepted in the job market. Even if they are accepted locally, accreditation authorities internationally still do not recognize these degrees and this often becomes a major drawback for those students who have acquired such degrees at a substantial cost, both time and money.

The more important question, however, is not about the validity of their degrees, but about the nature of the "knowledge" they impart. Graduates of higher educational institutions (both public and private alike) in developing countries like Pakistan, tend to 
struggle to find jobs. Employers on the other hand complain of the acute shortage of skilled human resource. This discrepancy between supply and demand is a result of often outdated and/or impractical curriculums taught in the majority of higher educational institutions. There is little or no focus on practical experience of theoretical concepts and even the theory is taught in a manner so as to facilitate rote memorization as opposed to conceptual understanding. The end results are a barrage of graduates with degrees from fancy sounding but hollow institutions who have little idea about how their theoretical learning of college or university is applied in the industry.

Additionally, as the UNESCO (2007) report notes as well that the drive for profit has pushed private universities to emphasize those subjects that have direct market value, such as business administration and computer studies. This tendency has reduced the chances of such disciplines like philosophy, psychology or history. The degradation and devaluation of liberal arts and social science disciplines in Pakistan is a sorry reflection of this short-term vision which is dictated by society and by the industry's need for manpower. Because of this over-emphasis on churning merely good managers or competent business associates, or generally speaking "the most employable candidates", most colleges and universities have also long since forgotten their more imperative duty of producing not just manpower but relatively moderate individuals that play their due share in contributing to the social fabric of the human family. Educational institutions are meant to be potent agents of socialization, an active breeding ground not just for gaining information on a particular academic discipline, but for more general social and moral grooming. This is clearly not the case in the vast majority of Pakistani educational institutions.

\section{Standard of Research at Higher Education Level:}

In Pakistani educational system, which doesn't produce curious minds and innovative thinking, the research activities are based on parallel research. Unfortunately the standard of Research at higher education (M.Phill and $\mathrm{PhD}$ ) is low.

Ultimately, what is needed is a complete restructuring of the system. Because the problems of Pakistan's educational set up are themselves multifaceted, the solutions too will need to come from multiple levels. The state alone, given the nature of Pakistani 
governmental setup and the fragmented society it caters to, cannot be realistically expected to carry the load of educating the country's youth. A model based on privatepublic partnership may be the need of the hour, but any concrete improvements may be impossible unless education becomes a priority on the agenda of not only the state and its decision and policy making organs, but all stakeholders at every level of society. As a community the people of Pakistan collectively need to remind themselves of the true purpose of education, so they may better train the students of present time to approach education with a broad and healthy mindset.

Ascertaining the contribution of Media in the commercialization of education

In today' globalized context the influence and need of Media for the economic as well as the overall development has increased considerably. Education is the decisive force that contributes to the development of any society. For the improvement of the educative process in terms of productivity and marketability the role of Media cannot be denied. Media's role is tremendous in this respect, however, out of the three forms of education media plays significant role in the informal as well as non-formal education. Through media services an environment is created that brings initial awareness among the masses regarding any important aspect of the social life.

In the context of Pakistan, the need of an active media for the betterment of society through education has increased manifold. The geo-political and strategic location of Pakistan demands a vibrant, effective, and dynamic manpower to reap the fruits of the growing scenario, especially in the face of the latest China Pakistan Economic Corridor (CPEC) which is a matter of debate for many global powers. In this respect the importance and role of Media can be assessed from the following aspects:

The word Media is a derivation of the term Medium, meaning carrier or mode. It means to design an item in such a manner to be made understandable for all and sundry. This term was initially used for plain sources of information such as: newspapers, journals, and magazines etc. but with the inventions of the modern science and technology it attained a relatively broader concept covering transistor radio, Tele Vision, motion pictures, projector, cinemas, computer, mobile and Internet etc. In today's globalized context Media has attained enormous focus and attention. It positively 
contributes to the development of society. It keeps the people informed, educated and also provides entertainment to the masses. It keeps the human family aware and updated. It has tremendous bearings upon society with reference to culture and civilization. As a potential source it is usually used to mould the public opinion in a particular direction. It is equally important in war and peace.

Media is important for education as well. It affects students' knowledge and information. Due to the impact of Media the World has shrink to a sort of global village. It connects students and the general public from one part of the globe to another part of the globe. In modern times, education likewise, has attained an international aspect. It has to foster cultural diversity and international understanding that leads to have respect for life and global citizenship. It has a number of functions some of which are discussed below.

\section{Provides general information:}

Mass media is the strongest source of disseminating information among the masses. It is the quickest and easiest source of knowledge and information.

\section{Provides vocational information:}

It provides quick and easy opportunities for vocational knowledge and skills as well as professional information to the inhabitants of any society.

\section{Spreads awareness and civic responsibility:}

Media solicits civic responsibility among the masses. Various problems and issues are highlighted by media and a futuristic stance is developed based o the prospects. An effective means of informal Education:

Human learning is more contexts oriented, hence; Media provides context related knowledge.

\section{Contributes as a non-formal agency:}

Due to its overwhelming influence, media is now-a-days considered a nonformal agency of education. It is predicted that in future, media will take over the actual classroom teaching. Furthermore, media is the cheapest, quickest and easiest source of educating the people irrespective of age limits.

The discussion above reveals that media has very significant role in connecting 
people from around the world. This concept is also highlighted by Rolls who believes that through internet students are connected throughout the World (Rolls, 2007). For this purpose teachers and students need to be 'media literate'. In this connection Schwarz emphasize for university teachers the need of 'media literacy' based Teacher education (Schwarz, 2001). Similarly, the establishment of a media center was earlier expounded by Poston who believed that many professionals and educational organizations have felt the need of Media center inside the educational organizations especially at university level (Poston, 1978).

\section{CONCLUSION}

From the above discussion it can safely be concluded that media plays tremendous role in the uplift of any society. Commercializing higher is no doubt, no exception to this rule. So it is high time to commercialize higher education in Pakistan through the influence of media. The specific situation that is going to be created after the CPEC, it is the need of the hour to hour to make higher education more potential for the emerging challenges. Looking at CPEC as a special case for example, some new disciplines need to be introduced in the universities located especially on the Economic Corridor. Of course, the study and learning of Chinese language can be one such area together with some skill-oriented disciplines that would be required in the smooth and successful flow of transit trade between and among the linked countries. This can boost the supply and demand aspect of the skilled man power prepared in the Pakistani Universities.

If Government and private sector pay due attention to the education sector as a prime objective, the standard of education can be upgraded in Pakistan. The Government should increase the salaries of teachers so that they can pay due attention to the students. Government should have a Quality Management cell to upgrade the standard of education. The courses of all levels should be reviewed in the light of national interests and the educational institutions. Providing fake degrees must be banned. Moreover, there is a dire need to increase the budget allocation to education to enhance the capability and performance of the educational institutes and teachers as well. Primary education must focus with maximum available resources for better results in early age of the students. 
The focus should be on student exchange programs between developed and underdeveloped nations. Last but not least, the uniform educational system should be established with consensus among the stakeholders.

Recommendations: The following recommendations are suggested for making higher education more potential for the upcoming challenges.

- Education sector should be made free from politics and all decisions should be based on merit.

- On the other hand, every nation of the world such as UK, USA, China, France, Germany, Japan, Russia etc. have their own system of education based on their culture, language and traditions. So national language be given preference.

- May factors constitute to the educational dilemma including: shortage of teachers and poorly equipped laboratories, out-dated curriculum, defective curricula, dual medium of instruction, cheating in the examinations together with overcrowded classrooms. Such issues may be immediately addressed.

- At least $10 \%$ of budget may be allocated to education.

- Proper reward and punishment system be introduced. Teacher's organization and NGOs should be awarded prizes when they achieve targets.

- The courses of all levels should be revised, reviewed and improved in the light of national interests.

- The Universities and educational institutions providing fake degrees must be discouraged and banned.

- All Research thesis of Master, M. Phil and Ph. D level should be available on the web-site of the universities.

- Government should have a Quality Management cell to upgrade the standard of education. Ghost schools must be closed and culprits may be awarded due punishment.

- New disciplines may be introduced in higher education that may cater for the post CPEC challenges.

- The study of Chinese language may be started in universities. 


\section{REFERENCES}

Akbar, M. Wasim, Literacy Issue and Media (April 2002) Monthly Afkar-e-Muallim, Lahore, Page.64 Akbar, M. Wasim (2003) Zarae Iblagh aur Islam, Makka Publishers, Lahore P.76

Akbar, M. Wasim (2004) Musalman Ustad personality \& Character, Waheed Art Press, D I Khan P.15

Ameen Javed (1992) Madaniat Pakistan, Aiwan Adab, Lahore P. 335

Carrol, J. B. (1995). The teaching of French as a foreign Language, John Willy and Sons, New York, P.45

Atta-e-Rehman, an article, The Daily The news, Rawalpindi, 17 Sept.2011, the four pillars for progress

Daily Express Peshawar (Feb 16, 2007)

Federal Bureau of Statistics (2010). Ministry of Finance, Government of Pakistan.

HEC (2010). http://www.hec.gov.pk/InsideHEC

National report of UNESCO, Education in Pakistan, 2007.

Rolls, A. (2007) The Reference Shelf: International Perspectives on Education. USA: The H.W. Wilson Company.

Schwarz, Gretchen, (2001). The Role of Media Literacy in Teaching Education. Teacher Education Quarterly, retrieved on September 20 2007, from www.findarticles.com.

Poston, Teresa. (1978). Concept of school media center and its services. Peabody Journal of Education, 55, 188-204. Retrieved on September 23 2007, from JSTOR Database.

Committee on Teacher Education (1976) Curriculum on lines, Ministry of Education, Islamabad, Pakistan, P.201

National Education Policy (1992) Govt. of Pakistan (1992-20) Ministry of Education Islamabad, Pp.26-62

National Commission on Education (1959), Govt. of Pakistan (1992-20) Ministry of Education Islamabad, Pp.265

National Committee on Teachers Education (1976), Curriculum online, Ministry of Education P-201

National Education Policy (1992) Govt of Pakistan (1992-20), Ministry of Education Islamabad, Pp.89 